Abstracta Iranica Abstracta Iranica

Revue bibliographique pour le domaine irano-aryen

Volume 32-33 | 2013

Comptes rendus des publications de 2009-2010

\title{
Matthew P. Canepa. Technologies of Memory in Early Sasanian Iran: Achaemenid Sites and Sasanian Identity
}

\section{Astrid Nunn}

\section{(2) OpenEdition}

1 Journals

\section{Édition électronique}

URL : http://journals.openedition.org/abstractairanica/40482

DOI : 10.4000/abstractairanica.40482

ISSN : 1961-960X

Éditeur :

CNRS (UMR 7528 Mondes iraniens et indiens), Éditions de l'IFRI

\section{Édition imprimée}

Date de publication : 1 décembre 2013

ISSN : 0240-8910

\section{Référence électronique}

Astrid Nunn, « Matthew P. Canepa. Technologies of Memory in Early Sasanian Iran: Achaemenid Sites and Sasanian Identity ", Abstracta Iranica [En ligne], Volume 32-33 | 2013, document 148, mis en ligne le 01 juillet 2016, consulté le 27 septembre 2020. URL : http://journals.openedition.org/abstractairanica/ 40482 ; DOI : https://doi.org/10.4000/abstractairanica.40482

Ce document a été généré automatiquement le 27 septembre 2020.

Tous droits réservés 


\title{
Matthew P. Canepa. Technologies of Memory in Early Sasanian Iran: Achaemenid Sites and Sasanian Identity
}

\author{
Astrid Nunn
}

\section{RÉFÉRENCE}

Matthew P. Canepa. « Technologies of Memory in Early Sasanian Iran: Achaemenid Sites and Sasanian Identity ». AJA, 114, 2010, p. 563-596.

1 Les rois sassanides, parmi eux surtout les premiers Ardešīr I et Šāpūr I, se forgèrent une identité qui élimina l'héritage séleucide et d'époque des Frataraka pour se tourner vers celui de leur propre pays. Les créations achéménides les inspirèrent dans leur art et les aidèrent à se créer une légitimation politique. Outre les stucatures des palais de Qal'e DoHtar et d'Ardešīr-Xwarrah, le monument le plus caractéristique est celui des tombes à Naqš-e Rostam. Certains détails dans la représentation des cheveux, des couronnes, des draperies et des chevaux sur ces reliefs d'Ardešīr sont directement inspirés des reliefs de Persépolis. À Bishapur l'on retrouve les corniches et les protomes taurins.

\section{AUTEURS}

ASTRID NUNN

Université de Munich 